\title{
Chapter 10 \\ Case: Sharing Parts and Services Among NATO Members
}

\author{
Semra Türkalp and Bastiaan Dekkers
}

\begin{abstract}
Contents

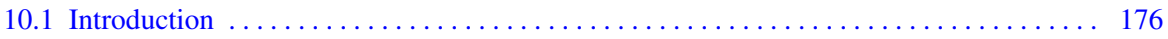

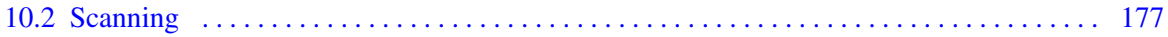

10.3 Analysis $\ldots \ldots \ldots \ldots \ldots \ldots \ldots \ldots \ldots \ldots \ldots \ldots \ldots \ldots \ldots \ldots \ldots \ldots \ldots \ldots \ldots \ldots \ldots$

10.3.1 Macro-level: Fragmentation of the Arms Export Control Laws

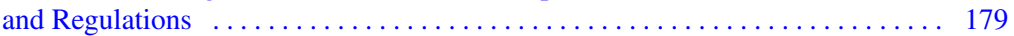

10.3.2 Meso-level: No Institutionalised Compliance Culture Within the NATO . . . . 180

10.3.3 Micro-level: Operational Readiness Versus Compliance . . . . . . . . . . . 181

10.4 Response $\ldots \ldots \ldots \ldots \ldots \ldots \ldots \ldots \ldots \ldots \ldots \ldots \ldots \ldots \ldots \ldots \ldots \ldots \ldots \ldots$

10.4.1 Leadership Commitment to the Implementation of the Arms Export

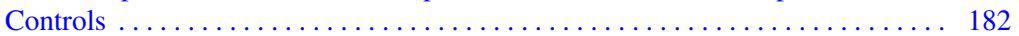

10.4.2 The NSPA as the Leading NATO Agency to Create a Culture of Compliance . . . . 183

10.4.3 Common Agreement on the Basic Rules of Arms Export Controls . . . . . . . 183

10.4.4 Formalization of the Implementation of Arms Export Control

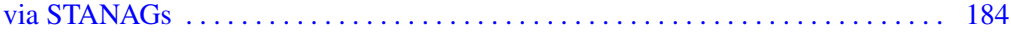

10.4.5 Periodic Arms Export Controls Training to Member States' Personnel . . . . . 184

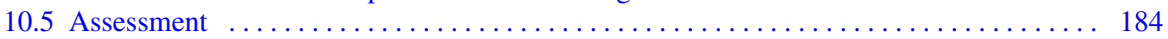

References $\ldots \ldots \ldots \ldots \ldots \ldots \ldots \ldots \ldots \ldots \ldots \ldots \ldots \ldots \ldots \ldots \ldots \ldots \ldots \ldots$
\end{abstract}

\begin{abstract}
NATO's goals require close cooperation of Member States on operational readiness, interoperability of their systems, material supplies, transfer of technology and joint R\&D projects. A common approach on the application and implementation of arms export controls, however, is largely lacking. This chapter questions the absence of application and implementation of arms export controls in the context of the material logistical support and services provided by the NATO Support and Procurement Agency (NSPA). Three root causes of deviant behaviour of the Member States with the arms export controls are identified and analysed: (1) fragmentation of the arms export control laws and regulations; (2) a lack of leadership commitment and organisational culture of compliance; and (3) a combination of external
\end{abstract}

\footnotetext{
S. Türkalp $(\varangle) \cdot$ B. Dekkers

Royal Netherlands Air Force, PO Box 8762, 4822 ZW Breda, The Netherlands

e-mail: s.turkalp@mindef.nl

B. Dekkers

e-mail: bcj.dekkers@mindef.nl
}

R. Beeres et al. (eds.), NL ARMS Netherlands Annual Review

of Military Studies 2021, NL ARMS,

https://doi.org/10.1007/978-94-6265-471-6_10 
and internal pressures leads to a forced prioritization of operational readiness above compliance. Next, a response is formulated to effectively counter deviant behaviour such as non-compliance with arms export controls by implementing a mixture of soft and hard controls. We advise the NSPA to create a culture of compliance within the NATO Partnership Program's community based on ethical values and virtues. This requires social consensus, leadership commitment and a common agreement on and formalization of the basic rules of export control.

Keywords Arms export controls • operational readiness $\cdot$ NATO • (non-)compliance $\cdot$ deviant behaviour $\cdot$ cooperation

\subsection{Introduction}

NATO is a political and military alliance whose principal task is to safeguard the freedom and security of all its 30 Member States by political and military means. Collective defence is at the heart of the Alliance and creates a spirit of solidarity and cohesion among its members. Today, the security environment is more complex and demanding than at any time since the end of the Cold War. NATO faces challenges and threats that originate from the east and the south, state and non-state actors, and military forces and terrorists. ${ }^{1}$ Therefore, it is imperative for the survival of the Alliance to strengthen its deterrence and defence posture by bolstering its readiness, responsiveness and reinforcement to respond swiftly and firmly to the full spectrum of current and future challenges and threats from any direction, simultaneously. The goals set by the Alliance to enhance its deterrence and defence posture require close cooperation of Allied Member States on operational readiness, interoperability of their systems, material supplies, transfer of technology and joint research and development projects. At the same time, close cooperation among the Member States necessitates a common approach by the Alliance on the application and implementation of arms controls, more specifically arms export controls, to prevent illicit trade and the proliferation of conventional arms, weapons of mass destruction or arms technology to hostile nations or non-state actors such as terrorist organisations.

To this end, the Alliance declared to pursue an active policy in harmonising defence and arms control policies and objectives within NATO. As one of the harmonising policies, the Alliance stated to be ready to support the implementation of the Arms Trade Treaty (ATT) which establishes common international standards for the import, export and transfer of conventional arms. ${ }^{2}$ However, various NATO civilian and military organisations and agencies that are assigned to assist, coordinate and support the Member States in the realisation of the Alliance's deterrence and defence goals such as the Defence Investment Division (DIV), NATO Science and Technology Organization (STO) and the NATO Support and Procurement Agency (NSPA) ${ }^{3}$ do

\footnotetext{
${ }^{1}$ NATO 2020b.

2 NATO 2020a.

${ }^{3}$ NATO 2020d.
} 
not have a common arms export controls policy, an integrated program, regulations to assist and support the Member States to cooperate on operational readiness and training, i.e. transfer of controlled material supplies, services and technology among them and/or with commercial parties responsibly and arms export control compliant under the NATO umbrella.

In this chapter, we will question the absence of application and implementation of arms export controls in the context of the material logistical support and services provided by the NSPA. As NATO's appointed primary enabler, the NSPA's mission under the North Atlantic Council (NAC) Charter is to provide "cradle to grave" support and services to the Allied Member States in logistics, infrastructure, operations and systems. ${ }^{4}$ To do so, the Agency procures supplies, repairs and maintenance services, demilitarization equipment, security items, repair materials and engineering/technical support from more than 10.000 companies across the world registered in the NSPA source file. These companies and the Member States are actively doing business with each other via the NATO Logistics Stock Exchange (NLSE) program, a secure and web-based e-Business application linking Armed Forces and Suppliers via a single electronic marketplace. ${ }^{5}$ Yet in the from "cradle to grave" process no attention is paid to the arms export controls. ${ }^{6}$

Based on the Problem-Oriented Policing (POP) framework, ${ }^{7}$ our chapter provides an in-depth examination of the Member States' deviant behaviour of not applying or of circumventing arms export controls in the context of the NLSE program under the NSPA's coordination and support, while the Alliance clearly stated as an objective to actively pursue a policy of effective arms controls in the light of collective defence. First, we will identify the deviant behaviour in a (hypothetical) case. Next, we will provide a root cause analysis of the deviant behaviour and formulate responses on macro-, meso- and micro-level to prevent the re-occurrence of the deviant behaviour. Finally, we will reflect on the analysis and the effectiveness of the responses, and assess the lessons learned for the future.

\subsection{Scanning}

As one of the NATO countries, a fictitious European NATO Member State (hereafter EUMS) is heavily dependent on the United States (US) government weapon systems and technology, which are in most cases acquired through the Foreign Military Sales (FMS) Program under the Arms Export Control Act. The arms export control regime of the US is mainly based on foreign policy and national security concerns which are subject to constant changes depending on the geopolitical environment of that moment and the dynamics within the US. Some of the NATO countries such as

\footnotetext{
${ }^{4}$ NATO 2020e.

${ }^{5}$ NATO 2020c.

${ }^{6}$ NATO 2020c.

${ }^{7}$ Braga 2008.
} 
Cyprus, Albania and Turkey are under US scrutiny and subject to the US sanctions. If the EUMS violates the US arms export control regulations, the EUMS will be excluded from the US weapons program or receive systems based on lower US technology. Therefore, the EUMS has a firm US export control laws and regulations oriented Arms Export Control Compliance Organization (AECCO) and an advanced Internal Compliance Program (ICP) in place. Every re-export or transfer is registered in the internal Export Control Database and scrutinized by the AECCO accordingly the export control procedures and processes in the ICP, whether a re-export or transfer request of a defence article, service or technology to a third party can be authorized or not. Additionally, all third parties are checked on the US and EU sanction lists before the re-export or transfer requests are approved.

Yet during the NATO defence exercises, when parties are expected to share spare parts through the NLSE program with the participating Member States to maintain the availability of weapon systems, the EUMS material logistics personnel do not register the re-export or transfer requests in the internal Export Control Database. This is because the pressure to cooperate with the Member States and to act quickly on the NLSE requests to safeguard the readiness of the weapon systems for the NATO exercises gain the upper hand over the complexity of the arms export controls systems. Especially since the EUMS is one of the few Member States to implement and apply the related export control laws and regulations and has advanced procedures/processes in place, whereas most other Member States are not familiar or have a poor understanding of arms export controls and do not have the required procedures, processes and or qualified personnel in place.

So the complexity of the unilateral application and enforcement of arms export controls by the EUMS presents it with a dilemma. Either the EUMS clashes with the other Member States accusing EUMS of distrusting its Allies and not acting in good faith, thereby running the risk of being excluded from the NATO Programs or exercises, or the EUMS gives in to the pressure to act as a reliable and cooperative member by setting its own arms export controls aside and hence committing export control violations. Moreover, the NSPA as the primary assisting and supporting NATO agency to the Partnership Programs officially states that Member States themselves are responsible and accountable for whether they apply or implement the arms export controls.

Based on this, in the next section, we will identify a possible root cause for the deviant behaviour of the Member States such as the EUMS under the NATO Partnership Programs on the macro-, the meso- and the micro-level. ${ }^{8}$

\footnotetext{
${ }^{8}$ Elias 2013, p. 39.
} 


\subsection{Analysis}

\subsubsection{Macro-level: Fragmentation of the Arms Export Control Laws and Regulations}

Arms export control laws and regulations are based on national, regional and international laws and therefore differ for each Member State. As sovereign entities, States are free to decide whether or not to adopt laws to regulate and limit the exports of arms, dual-use goods and technologies for national security purposes and/or foreign policy objectives. However, at the same time, as participants of the international system, most states are bound by International Treaties and/or the United Nation Security Council Resolutions which regulate arms Export or even impose arms embargoes on some States. For example, the ATT and United Nations Security Council Resolutions 1540 and $2420 .^{9}$

Additionally, there are several Multilateral Export Control Regimes (MECR) such as the Wassenaar Arrangement (WA), and the Australia Group. Although not binding, these MECRs promote transparency and greater responsibility in the transfer of arms, dual-use goods and technology among its members. ${ }^{10}$ The WA as one of the most influential regimes, produced two Control Lists: (1) the Munitions List and (2) the List of Dual-Use Goods and Technologies, to prevent unauthorized exports and reexports of those items and technologies. ${ }^{11}$ All NATO Member States, except Iceland, Montenegro, Albania and North Macedonia, are members of the WA and agreed to commit themselves to the two Controlled Lists.

On the regional level, the European Union (EU) has its own laws and regulations on arms export controls, although harmonized with international treaties, MECR and the UN Resolutions. The Dual-Use Regulation 428/2009, Annex I and IV (compatible with the WA) are directly applicable to all EU Member States. While allowing the Member States to export and re-export freely between them, the regulation imposes controls such as licensing for exports and re-exports to third parties outside the EU. Licensing and the enforcement of the regulation is delegated to each Member State to implement. Based on its shared competence on the matters of the Union's Common Security and Foreign Policy, the EU also introduces a Common Military List (again compatible with the WA) and several directives to harmonize the national arms export control regimes of its Member States. ${ }^{12}$ Additionally, the EU has its own sanction regime alongside the United Nations and the US. The complexity of the EU's institutional framework and its related competencies to regulate or partially regulate export controls adds up to the already highly complex web of arms export control regimes.

\footnotetext{
${ }^{9}$ Aubin and Idiart 2016, p. 24.

${ }^{10}$ Aubin and Idiart 2016, p. 28.

${ }^{11}$ Wassenaar Arrangement Secretariat 2020.

12 Aubin and Idiart 2016, p. 124.
} 
As outlined above, it is very challenging for the Member States to understand and interpret the vague provisions of these layered and complex treaties, regulations, agreements and arrangements on arms export controls on their own, and to identify and implement those provisions properly into their national laws and apply uniformly among them. As argued by Tukamuhabwa, ${ }^{13}$ knowledge of the law improves compliance while a lack of familiarity with the rules results in poor compliance levels. Yet, rules must also be clear. Lack of clarity of rules equally increases the possibility for unintentional and deliberate non-compliance. ${ }^{14}$

Based on this, we conclude that NATO Member States' poor knowledge and understanding of arms export controls due to the complexity and fragmentation of the laws and regulations, and the discrepancy in the implementation and enforcement, highly contribute to the deviant, non-compliant behaviour of the Member States.

\subsubsection{Meso-level: No Institutionalised Compliance Culture Within the NATO}

As mentioned earlier, the Alliance declares to remain committed to arms controls, disarmament and non-proliferation, and to pursue an active policy in harmonising defence and arms control policies and objectives within NATO. Yet, in practice, NATO's effort on arms control and non-proliferation remains limited to a general political declaration of its adherence to the International Treaties such as the ATT and a couple of small projects on disarmament of Small Arms and Light Weapons (SAWL) in the Balkans conducted under the supervision of the NSPA. ${ }^{15}$

Pursuing an active policy on arms controls and non-proliferation would require the highest level of the organisation, such as the NAC, to come up with an official statement and a clear working program tasking the NATO's organisations and agencies such as the NSPA as the primary enabler, support and service provider, to implement arms controls in practice within in the context of the NATO Partnership Programs. When top management initiates and supports compliance, it would spread in the entire organisation. The main goal is to have a NATO organisation with a culture of compliance that will motivate all stakeholders to comply with the rules. Studies have proven that culture plays a central role in the compliance process and associated outcomes if the culture is characterised by specific values such as openness, trust and honesty. ${ }^{16}$ Moral obligation and social influence affect compliance. However, the NSPA's current approach to the implementation of the arms export controls is dismissive, declaring that each Member State is responsible and accountable for its own export, re-export or transfers of arms and technology.

\footnotetext{
13 Tukamuhabwa 2012.

14 Tukamuhabwa 2012.

15 NATO 2021.

16 Tukamuhabwa 2012.
} 
Even the standardization agreement (STANAG) 2034 on Standard Procedures For Mutual Logistic Assistance does not include any provisions or moral obligation referring to the arms export controls or any procedures or checks to act in compliance with arms export controls, e.g. embedded in the ATT. Furthermore, the organisation is not clear or transparent about its own procurement processes. The NSPA has more than 60.000 companies and partners registered in its source file, more than 10.000 of them already do business within the context of the NLSE Program. ${ }^{17}$ Yet, no NSPA procedures or processes, internal or external are in place to make sure that these registered companies are checked and vetted against the arms export control regimes and/or sanctions and/or doing business in compliance with arms export control regimes.

Violations have consequences such as blacklisting, banning from the programs, blocking of further cooperation involving US technology and/or severe fines. Because of the ambiguous approach of the NATO to arms export controls and the Member States' reluctance towards arms export controls, the US pursues a very stringent export control policy concerning the NATO Partnership Programs. Each Member State is held responsible to request licenses or third-party approvals for every intended re-export or transfer of arms, dual-use goods or technologies. Member States such as the EUMS, which are highly dependent on US arms and technology, may encounter US restrictions when taking part in the NATO Partnership Programs, such as the NLSE.

We conclude that, as long as the NATO will not genuinely commit to the implementation of arms export controls at the highest level such as the NAC, and as long as the NSPA does not take the stage as an organisation imposing a culture of compliance, Member States will continue their deviant behaviour, hence noncompliance, or Member States will eventually abandon the NATO Programs because of the high pressure imposed by the US and its stringent export control policy.

\subsubsection{Micro-level: Operational Readiness Versus Compliance}

According to Tukamuhabwa, ${ }^{18}$ cognitive dissonance is the feeling of uncomfortable tension that comes from holding two conflicting thoughts in the mind at the same time. When persons are forced to do something they do not want to do, dissonance is created between their cognition and their behaviour.

The material logistics personnel of the EUMS are under constant pressure from their counterparts to act as a reliable and faithful partner in the achievement of the common goal to strengthen NATO's deterrence and defence posture and form their own organisation to make sure that the readiness of the weapon system is achieved as soon as possible. At the same time, the personnel is very aware of the applicable

\footnotetext{
17 NATO 2020e.

18 Tukamuhabwa 2012.
} 
arms export control laws and regulations and procedures that must be followed to get approval from the AECCO. Yet, combined, the external pressure and internal pressure incentivize the personnel to circumvent the export controls by not registering the items in the database and denying the AECCO. Moreover, there is no monitoring system in place to bring violations to the AECCO's attention.

In sum, high psychological pressure, externally and internally induced on the material logistic personnel of the EUMS to act as a faithful ally in pursuit of the common purpose, pushes the personnel over the edge to circumvent the arms export controls, and commit violations. The absence of a monitoring system or a whistle blow line makes it possible to commit violations without any consequences.

\subsection{Response}

In this section, we propose effective responses to the identified root causes of the non-compliant behaviour concerning the arms export controls at the organisational level in the context of NATO Partnership Programs. Our target for intervention is the NSPA. The responses are a mix of hard controls and soft controls with short- and long-term effects.

\subsubsection{Leadership Commitment to the Implementation of the Arms Export Controls}

As discussed in the previous sections, NATO declares to be committed to an active policy in arms control, disarmament and non-proliferation within NATO and refers to several international treaties and agreements on arms controls. However, although made at the NAC level, this declaration is more of a general political statement than a true commitment to the implementation of arms controls, hence arms export controls. The NAC's genuine commitment to arms control should firstly be demonstrated by a strong and clear institutional support to promote a culture of compliance, ${ }^{19}$ and secondly by making available adequate resources to the NATO Agency delegated with sufficient authority and autonomy to deploy policies and procedures on arms export controls and to fully integrate into the day-to-day operations of the NATO. The NSPA as the primary enabler of the NATO and support and service provider of the NATO Member States should therefore be the appointed Agency with the delegated powers to effectively implement arms export controls. Additionally, the Agency possesses the necessary experience, knowledge and expertise and is already tasked with overseeing arms control and disarmament projects within the NATO.

${ }^{19}$ Tukamuhabwa 2012. 


\subsubsection{The NSPA as the Leading NATO Agency to Create a Culture of Compliance}

According to Tukamuhabwa, ${ }^{20}$ an organisation with a genuine commitment to compliance is evidenced by top leaderships' dedication to ethical behaviour. Ethical leadership promotes ethical conduct at various levels, not only directly influences immediate followers but also indirectly influences the ethical cognitions and behaviours of the followers at the lower levels by replication of ethical behaviours of the leaders and embedding of shared understanding that represents ethical culture. ${ }^{21}$ The NSPA's mission statement, supported by the NAC, should promote the values the Alliance stands for by aligning itself with the commitment to the arms controls in the light of the collective security. An example of such a statement could be as follows: As the primary enabler, the NSPA provides support and services to the NATO Nations in the light of strengthening deterrence and defence posture of the Alliance in order to be able to counter current and future threats, meanwhile being committed to the arms control, disarmament and non-proliferation.

To create a culture of compliance within the NATO and among the Member States, it is imperative for the NAC and the NSPA to act as ethical leaders and promote: (1) clarity (e.g., adopt a normative framework such as a Code of Conduct which makes clear what is expected concerning arms export controls); (2) transparency (e.g., be transparent about acquisition processes and the suppliers by publishing its vetting and decision-making procedures; publish annual reports on arms exports per member state and commercial parties involved; encourage Member States to provide information, data and records of their annual transactions); (3) supportability (e.g., use social influence on compliance, and build social consensus among the community to be compliant; skilled personnel to assist the Member States to implement arms export controls and mediate between them where necessary); (4) discussability (e.g., create a forum to discuss openly the issues encountered with the complexity of the arms export controls); (5) accountability and sanctionability (e.g., implement a reward and punishment system to encourage compliant behaviour and discourage dismissive, deviant behaviour among the Member States). ${ }^{22}$

\subsubsection{Common Agreement on the Basic Rules of Arms Export Controls}

The fragmentation and the complexity of the arms export control laws and regulation are identified as root causes for deviant behaviour and discussed in the Analysis Phase. The NSPA should take the lead to reach a common agreement on the basic arms

\footnotetext{
20 Tukamuhabwa 2012.

21 Schaubroeck et al. 2012.

22 Bogers 2018, p. 48.
} 
export control rules to be applied among the Member States within the framework of NATO Partnership Programs. ${ }^{23}$

\subsubsection{Formalization of the Implementation of Arms Export Control via STANAGs}

Formalization of the commonly agreed arms export control rules should be incorporated in NATO STANAGs, specifically STANAG 2034 on Standard Procedures For Mutual Logistic Assistance, in order to be able to hold all Participating Nations formally accountable and responsible in case of non-compliance. As Tukamuhabwa states, sustained enforcement action instils a culture of compliance and has a direct effect on compliant behaviour. ${ }^{24}$

\subsubsection{Periodic Arms Export Controls Training to Member States' Personnel}

The NSPA should provide training on arms export controls to the Member States to increase awareness and to train Member States' personnel on how to apply arms export controls in their day-to-day practice without leading to any operational impediment. Via training, it is important to remove the presumed contradiction between operational readiness and compliance which eventually results in deviant behaviour. Training could also be a vehicle to bring the personnel (e.g., material logistics) of the Member States directly or indirectly involved in the Partnership Programs together to discuss their personal experiences and the dilemmas they face when they are put under pressure to prioritize operational readiness above arms export controls. Through this training, the arms export control procedures and processes of the Member States can be harmonized and aligned, which in the long term will have a positive effect on compliance.

\subsection{Assessment}

We have used the POP-framework to identify and analyse the root causes of deviant behaviour/non-compliance of the Member States with the arms export controls in the context of the NATO Partnership Program. Based on our analysis, we have proposed responses to target the root causes of deviant behaviour by Member States. Three root causes have been identified: (1) fragmentation of the arms export control laws

\footnotetext{
${ }^{23}$ Aubin and Idiart 2016, p. 10.

${ }^{24}$ Tukamuhabwa 2012.
} 
and regulations; (2) a lack of leadership commitment and organisational culture of compliance; and (3) a combination of external and internal pressures leads to deviant behaviour by the individuals, such as the material logistics personnel of EUMS, forced to prioritize operational readiness above its own arms export control laws and regulations. We have formulated a response to effectively counter deviant behaviour and prevent the reoccurrence of non-compliance with arms export controls by implementing a mixture of soft and hard controls.

Yet our main focus has been the role of the NSPA, as the organisation appointed and delegated by the NAC to create a culture of compliance within the NATO Partnership Program's community based on ethical values and virtues. Because a shared understanding of values means that members recognize a particular feeling, experience or activity as normal. In such cases, they are expected to be more cognizant of ethical issues, to avoid unethical conduct and discourage unethical conduct in others. Furthermore, social consensus is formed in such a way that the unit penalizes unethical behaviour, rewards virtuous behaviour and maintains strong ethical norms.

However, strong and clear leadership commitment is required by the NAC towards arms export controls, supported by adequate resources to effectuate a culture of compliance. Meanwhile, a common agreement on the basic rules of arms export control and its formalization through STANAGs will positively contribute to the compliant behaviour and enable the NSPA and Member States to keep each other accountable in case of a violation.

\section{References}

Aubin Y, Idiart A (2016) Export Control Law and Regulations Handbook: a practical guide to military and dual-use goods trade restrictions and compliance, 3rd edn. Kluwer Law International BV, Alphen aan den Rijn

Bogers JJD (2018) Control with care: the value of soft controls in the management control system of the Dutch Defence organization. Erasmus Universiteit Rotterdam, Rotterdam

Braga AA (2008) Problem-oriented policing and crime prevention, 2nd edn. Willow Tree Press, New York

Elias SM (ed) (2013) Deviant and criminal behavior in the workplace. New York University Press, New York

NATO (2020a) Arms Control, Disarmament and Non-proliferation in NATO. https://www.nato.int/ cps/en/natohq/topics_48895.htm Accessed 3 February 2021

NATO (2020b) Deterrence and Defence. https://www.nato.int/cps/en/natohq/topics_133127.htm Accessed 20 April 2021

NATO (2020c) NSPA I NATO Logistics Stock Exchange (NLSE). https://www.nspa.nato.int/about/ support-to-operations/nlse Accessed 2 March 2021

NATO (2020d) NATO Organization and Structure. http://www.nato.int/cps/en/natohq/structure.htm Accessed 2 March 2021

NATO (2020e) NSPA I NATO Support and Procurement Agency (NSPA). https://www.nspa.nato. int/about/nspa Accessed 2 March 2021

NATO (2021) NATO's role in conventional arms control. http://www.nato.int/cps/en/natohq/topics_ 48896.htm Accessed 3 March 2021 
Schaubroeck JM, Hannah ST, Avolio BJ et al. (2012) Embedding Ethical Leadership Within And Across Organization Levels. Acad Manage J 55:1053-1078

Tukamuhabwa BR (2012) Antecedents and consequences of public procurement noncompliance behavior. J Econ Behav Stud 4:34-46

Wassenaar Arrangement Secretariat (2020) The Wassenaar Arrangement. On Export Controls for Conventional Arms and Dual-Use Goods and Technologies. https://www.wassenaar.org/abo ut-us/. Accessed 2 March 2021

Semra Türkalp holds a Master in Public International Law from the University of Amsterdam, The Netherlands. Currently she works as Legal Counsel Trade Compliance at the Royal Netherlands Air Force.

Bastiaan Dekkers holds a Bachelor in Small Business from the Rotterdam University of Applied Sciences. Currently he works as a NATO \& FMS liaison at the Royal Netherlands Air Force.

Open Access This chapter is licensed under the terms of the Creative Commons Attribution 4.0 International License (http://creativecommons.org/licenses/by/4.0/), which permits use, sharing, adaptation, distribution and reproduction in any medium or format, as long as you give appropriate credit to the original author(s) and the source, provide a link to the Creative Commons license and indicate if changes were made.

The images or other third party material in this chapter are included in the chapter's Creative Commons license, unless indicated otherwise in a credit line to the material. If material is not included in the chapter's Creative Commons license and your intended use is not permitted by statutory regulation or exceeds the permitted use, you will need to obtain permission directly from the copyright holder. 